\title{
PENGHARGAAN PROFESI GURU SEBAGAI AGEN PERUBAHAN
}

\author{
H. A. Marjuni \\ UIN Alauddin Makassar
}

\begin{abstract}
Appreciation for the success of teachers as agents of change is an extraordinary form of motivation for teachers. The competitive climate in the environment for teachers will be even more motivated. All teachers have expectations and compete for awards as outstanding and quality teachers in order to improve the professionalism of their duties. Apart from appreciation in a profession, it is no less important, namely protection in carrying out obligations both legally and in other ways. Protection greatly affects the productive performance of a teacher. Efforts to educate the nation's life are the responsibility of education, especially in preparing students to become subjects who fear God Almighty, have a noble character, are tough, creative, independent, democratic, and professional in their respective fields.
\end{abstract}

Keywords: Awards, Teachers, Achievers, Agents, and Change

\section{PENDAHULUAN}

Dalam upaya mencapai tujuan pendidikan, pemerintah melalui Undang-Undang Sisdiknas memberikan berbagai penghargaan kepada guru dan dosen. Penghargaan kepada guru diberikan pada tingkat satuan pendidikan, desa/kelurahan, kecamatan, kabupaten/kota, propinsi, nasional dan/atau internasional.

Menurut Undang-Undang No.14 tahun 2005 tentang guru dan dosen, menjelaskan tentang penghargaan guru yang menyatakan bahwa pasal 36 ayat 1, guru yang berpreatasi, berdedikasi luar biasa dan bertugas didaerah khusus berhak memperoleh penghargaan, sedangkan ayat 2, guru yang gugur dalam melaksanakan tugas di daerah khusus memperoleh penghargaan dari pemerintah, pemerintah daerah dan masyarakat. ${ }^{1}$

Pasal 37 ayat 1, penghargaan dapat diberikan oleh pemerintah, pemerintah daerah, masyarakat, organisasi profesi dan satuan pendidikan. Ayat 2, penghargaan dapat diberikan pada tingkat sekolah, tingkat kelurahan, tingkat kecamatan, tingkat kabupaten/kota, tingkat provinsi, tingkat nasional dan/atau internasional. Ayat 3, penghargaan kepada guru dapat diberikan dalam bentuk tanda jasa, kenaikan pangkat istimewa, finansial, piagam atau penghargaan lain. Ayat 4, penghargaan kepada guru dilaksanakan dalam rangka memperingati hari ulang tahun kemerdekaan Republik Indonesia, hari guru nasional, hari pendidikan nasional dan lain-lain. Pasal 38, pemerintah dapat menetapkan hari guru nasional sebagai penghargaan kepada guru yang diatur dengan peraturan perundang undangan.

\footnotetext{
${ }^{1}$ Undang-Undang Republik Indonesia Nomor 14 Tahun 2005 Tentang Guru dan Dosen
} 
Agar seseorang yang memiliki profesi guru dapat memotivasi diri dan merasa aman dalam menjalankan tujuannya sehingga dapat tercapinya tujuan untuk terselenggaranya seluruh proses pembelajaran dengan baik, sehingga kualitas pendidikan secra keseluruhan, kualitas pendidik, peserta didik menjadi lebih baik.

\section{KAJIAN TEORI}

\section{A. Pengertian Penghargaan Profesi Guru}

Menurut Kamus Besar Bahasa Indonesia penghargaan Profesi Guru artinya perbuatan menghargai atau sebagai bentuk apresiasi kepada pegawai. Dari kedua definisi tersebut maka dapat diketahui bahwa penghargaan terhadap Profesi Guru adalah suatu penghargaan yang diberikan kepada guru dan kegiatan melindungi guru dari hal-hal tertentu yang dapat mengganggu aktivitas keguruannya. ${ }^{2}$

Pada saat ini kesulitan pilihan hidup menjadi pendidik lebih berat dari masa sebelumnya. Di luar tantangan masalah ekonomi dan gaya hidup materialistis, hanya seorang guru yang mempertahankan idealisme memfasilitasi anak didiknya menumbuh kembangkan jati diri yang berkarakter yang bisa mempertahankan kehormatan sebagai pendidik. Artinya idealnya seorang guru harus memberikan dirinya secara total bagi dunia pendidikan, sebuah keadaan yang berat di tengah semua persoalan hidup yang harus dihadapi seorang guru. Maka perlu ada strategi untuk menyiasati beban-beban strukturaladministratif kependidikan agar tidak menjerat guru ke dalam perangkap yang melelahkan sehingga mereka melepaskan idealisme dan semangat yang dibutuhkan. Strategi ini antara lain adalah menciptakan kondisi yang memacu untuk terus-menerus belajar.

Guru yang berkualitas selalu mengembangkan profesionalismenya secara penuh. Dia tak akan merengek-rengek meminta diangkat sebagai pegawai negeri atau guru tetap sebab pekerjaannya telah membuktikan, kinerjanya layak dihargai. Mungkin ini salah satu alternatif yang bisa dilakukan guru untuk mengembangkan dan mempertahankan idealismenya pada masa sulit. Namun, idealisme ini akan kian tumbuh jika ada kebijakan politik pendidikan yang mengayomi, melindungi, dan menghargai profesi guru. Pemerintah sudah seharusnya menggagas peraturan perundang-undangan yang melindungi profesi guru, tidak peduli apakah itu guru negeri atau swasta, dengan memberi jaminan minimal yang diperlukan agar kesejahteraan dan martabat guru terjaga. ${ }^{3}$

Visi guru sebagai pelaku perubahan dan pendidik karakter. Menjadi pelaku perubahan, perubahan itu harus tampil pertama-tama dalam diri guru. Hal inilah yang menjadi pemikiran dan strategi utama bagi para guru agar mampu menjadi pelaku

${ }^{2}$ Departeman Pendidikan dan Kebudayaan, Kamus Besar Bahasa Indonesia, (Jakarta: Balai Pustaka, 2011)

${ }^{3}$ Endang Komara, "Perlindungan Profesi Guru di Indonesia". MIMBAR PENDIDIKAN:Jurnal Indonesia Untuk Kajian Pendidikan, Vol. 1(2) September, Bandung, Indonesia: UPI, Jakarta: Bumi Aksara, 2020 h.155. 
perubahan dan pendidik karakter yang sangat dibutuhkan oleh masyarakat kita dewasa ini. $^{4}$

Di zaman persaingan ketat seperti sekarang, kinerja menjadi satu-satunya cara untuk mengukur mutu seorang guru. Karena itu, status pegawai negeri, swasta, tetap, atau honorer tidak terlalu relevan dikaitkan gagasan tentang profesionalisme kinerja seorang guru. Di banyak tempat lembaga swasta yang besar dan maju, status pegawai tetap malah membuat lembaga pendidikan swasta tidak mampu mengembangkan gurunya secara profesional sebab mereka telah merasa mapan. Demikian juga yang menjadi pegawai negeri, banyak yang telah merasa nyaman sehingga lalai mengembangkan dirinya. Oleh karena itu guru harus kembali pada jati dirinya yaitu memiliki sifat-sifat tertentu, yaitu ramah, terbuka, akrab, mau mengerti, dan mau belajar terus-menerus agar semakin menunjukkan jati diri keguruannya.

Situasi ini tidak dapat diatasi dengan mengangkat seluruh guru honorer menjadi pegawai negeri, seperti tuntutan beberapa kelompok guru honorer maupun mengangkat guru tidak tetap menjadi guru tetap yayasan. Masalah ini hanya bisa diatasi jika pemerintah dan masyarakat memberi prioritas untuk menjaga, melindungi, dan menghormati profesi guru. Secara khusus, pemerintah harus memberi jaminan finansial secara minimal kepada tiap guru agar mereka dapat hidup layak dan bermartabat sebagai guru. Jaminan seperti ini hanya bisa muncul jika ada perlindungan hukum berupa peraturan perundang-undangan yang benar-benar memihak dan berpihak kepada guru.

\section{B. Penghargaan Guru Sebagai Agen Perubahan}

Sebagai tenaga profesional, guru memiliki hak yang sama untuk mendapatkan penghargaan, penghargaan diberikan kepada guru yang berprestasi, berprestasi luar biasa, berdedikasi luar biasa, dan/atau tugas didaerah khusus. Penghargaan kepada guru dapat diberikan pada tingkat satuan pendidikan, desa/kelurahan, kecamatan, kabupaten/kota, propinsi, nasional dan/atau internasional. Penghargaan itu beragam jenisnya, seperti satyalencana, tanda jasa, bintang jasa, kenaikan pangkat istimewa, finansial, piagam, jabatan fungsional, jabatan struktural, bintang jasa pendidikan, dan/atau bentuk penghargaan lain sesuai dengan peraturan perundang-undangan.

Pada sisi lain, peraturan perundang-undangan mengamanatkan bahwa pemerintah kabupaten wajib menyediakan biaya pemakaman dan/atau biaya perjalanan untuk guru yang gugur dalam melaksanakan pendidikan pembelajaran di daerah khusus, putra dan/atau putrinya berhak mendapatkan beasiswa sampai ke perguruan tinggi dari pemerintah pusat dan pemerintah daerah.

Penghargaan menghasilkan dua macam manfaat, antara lain:

1. Memberikan informasi. Penghargaan dapat menarik perhatian personil dan memberi informasi atau mengingatkan mereka tentang pentingnya sesuatu yang diberi penghargaan dibandingkan dengan hal yang lain.

\footnotetext{
${ }^{4}$ Imron, Ali. Kebijakan Pendidikan di Indonesia. Jakarta: Bumi Aksara, 2016
} 
2. Memberikan motivasi. Penghargaan juga meningkatkan motivasi personil terhadap ukuran kinerja, sehingga membantu personil dalam memutuskan bagaimana mereka mangalokasikan waktu dan usaha mereka.

Sebagai tenaga profesional, guru memiliki hak yang sama untuk mendapatkan penghargaan Dan kesejahteraan. Penghargaan diberikan kepada guru yang berprestasi, berprestasi luar biasa, berdedikasi luar biasa, dan/atau bertugas di daerah khusus. Penghargaan kepada guru dapat diberikan pada tingkat satuan pendidikan, desa/kelurahan, kecamatan, kabupaten/kota, provinsi, nasional, dan/atau internasional. Penghargaan itu beragam jenisnya, seperti satyalancana, tanda jasa, bintang jasa, kenaikan pangkat istimewa, finansial, piagam, jabatan fungsional, jabatan struktural, bintang jasa pendidikan, dan/atau bentuk penghargaan lain sesuai dengan peraturan perundang-undangan. ${ }^{5}$

Kebijakan Pengembangan Profesi Guru - Badan PSDMPK-PMP 65 Pada sisi lain, peraturan perundang-undangan mengamanatkan bahwa pemerintah kabupaten wajib menyediakan biaya pemakaman dan/atau biaya perjalanan untuk pemakaman guru yang gugur di daerah khusus. Guru yang gugur dalam melaksanakan pendidikan dan pembelajaran di daerah khusus, putera dan/atau puterinya berhak mendapatkan beasiswa sampai ke perguruan tinggi dari Pemerintah dan Pemerintah Daerah. Kesejahteraan guru menjadi perhatian khusus pemeritah, baik berupagaji maupun penghasilan lainnya. Guru memiliki hak atas gaji dan penghasilan lainya.

Gaji adalah hak yang diterima oleh guru atas pekerjaannya dari penyelenggara pendidikan atau satuan pendidikan dalam bentuk finansial secara berkala sesuai dengan peraturan perundang-undangan. Di luar gaji pokok, guru pun berhak atas tunjangan yang melekat pada gaji. Gaji pokok dan tunjangan yang melekat pada gaji bagi guru yang diangkat oleh pemerintah dan pemerintah daerah diberikan oleh pemerintah dan pemerintah daerah sesuai dengan peraturan penggajian yang berlaku. Gaji pokok dan tunjangan yang melekat pada gaji bagi guru yang diangkat oleh satuan pendidikan yang diselenggarakan oleh masyarakat diberikan berdasarkan perjanjian kerja dan/atau kesepakatan kerja bersama.

Penghasilan adalah hak yang diterima oleh guru dalam bentuk finansial sebagai imbalan melaksanakan tugas keprofesian yang ditetapkan dengan prinsip penghargaan atas dasar prestasi dan mencerminkan martabat guru sebagai pendidik profesional. Ringkasnya, guru yang memenuhi persyaratan sebagaimana diamanatkan dalam UU No. 14 Tahun 2005 dan PP No. 74 Tahun 2008, serta peraturan lain yang menjadi ikutannya, memiliki hak atas aneka tunjangan dan kesejahteraan lainnya. Tunjangan dan kesejahteraan dimaksud mencakup tunjangan profesi, tunjangan khusus, tunjangan fungsional, subsidi tunjangan fungsional, dan maslahat tambahan. Khusus berkaitan

${ }^{5}$ https://makalahkuy.blogspot.com/2020/02/makalah-perlindungan-dan-penghargaan.html diakses pada hari jumat tanggal 23 Oktober 2020 pada jam 22:20 
dengan jenis-jenis penghargaan dan kesejahteraan guru sebagai agen perubahan disajikan berikut ini.

\section{Penghargaan Guru Berprestasi}

Pemberian penghargaan kepada guru berprestasi dilakukan melalui proses pemilihan yang Ketat secara berjenjang, mulai dari tingkat satuan pendidikan, kecamatan dan/atau kabupaten/kota, provinsi, maupun nasional. Pemilihan guru berprestasi dimaksudkan antara lain untuk mendorong motivasi, dedikasi, loyalitas dan profesionalisme guru, yang diharapkan akan berpengaruh positif pada kinerja dan prestasi kerjanya. Prestasi kerja tersebut akan terlihat dari kualitas lulusan satuan pendidi dikan sebagai SDM yang berkualitas, produktif, dan kompetitif.

\section{Penghargaan bagi Guru Berdedikasi di Daerah Khusus/Terpencil}

Guru yang bertugas di daerah khusus, mendapat perhatian serius dari pemerintah. Oleh karena itu, sejak beberapa tahun terakhir ini, pemberian penghargaan kepada mereka dilakukan secara rutin baik pada peringatan Hari Pendidikan Nasional maupun pada peringatan lainnya. Tujuan penghargaan ini antara lain, pertama, mengangkat harkat dan martabat guru atas dedikasi, prestasi, dan pengabdian profesionalitasnya sebagai pendidik bangsa dihormati dan dihargai oleh masyarakat, pemerintah dan seluruh lapisan masyarakat Indonesia. Kedua, memberikan motivasi pada guru untuk meningkatkan prestasi, pengabdian, loyalitas dan dedikasi serta darma baktinya pada bangsa dan negara melalui pelaksanaan kompetensinya secara profesional sesuai kualifikasi masingmasing. Ketiga, meningkatkan kesetiaan dan loyalitas guru dalam melaksanakan pekerjaan/jabatannya sebagai sebuah profesi, meskipun bekerja di daerah yang terpencil atau terbelakang; daerah dengan kondisi masyarakat adat yang terpencil; daerah perbatasan dengan negara lain; daerah yang mengalami bencana alam; bencana sosial; atau daerah berada dalam keadaan darurat lain yang mengharuskan menjalani kehidupan secara prihatin. ${ }^{6}$

Pemberian penghargaan kepada guru yang bertugas di Daerah Khusus/Terpencil bukanlah merupakan suatu kegiatan yang bersifat seremoni belaka. Penghargaan ini secara selektif dan kompetitif diberikan kepada dua orang guru sekolah dasar (SD) Daerah Khusus dari seluruh provinsi di Indonesia. Masing-masing Dinas Pendidikan Provinsi diminta dan diharuskan menyeleksi dan mengirimkan dua orang guru daerah khusus, terdiri dari satu laki-laki dan satu perempuan yang Kebijakan Pengembangan Profesi Guru - Badan PSDMPK-PMP 67 berdedikasi tinggi untuk diberi penghargaan, baik yang berstatus sebagai guru pegawai negeri sipil (Guru PNS) maupun guru bukan PNS. Untuk dapat menerima penghargaan, guru SD berdedikasi yang bertugas di Daerah Khusus/Terpencil harus memenuhi kriteria umum dan khusus. Kriteria umum dimaksud antara lain beriman dan bertaqwa kepada Tuhan Yang Maha Esa; setia dan taat kepada

${ }^{6}$ Momon Sudarma, Profesi Guru:Dipuji, Dikritisi, Dan Dicaci (Jakarta: PT Raja Grafindo Persada, 2013), h.272. 
Pancasila dan Undang-Undang Dasar 1945; memiliki moralitas,kepribadian dan kelakuan yang terpuji; dapat dijadikan panutan oleh siswa, teman sejawat dan masyarakat sekitarnya; dan mencintai tugas dan tanggung jawabnya.

Kriteria khusus bagi guru SD Daerah Khusus untuk memperoleh penghargaan antara lain, pertama, dalam melaksanakan tugasnya senantiasa menunjukkan dedikasi luar biasa, pengabdian, kecakapan, kejujuran, dan kedisiplinan serta mempunyai komitmen yang tinggi dalam melaksanakan fungsi- fungsi profesionalnya dengan segala keterbatasan yang ada di daerah terpencil. Kedua, tidak pernah dijatuhi hukuman disiplin tingkat sedang atau tingkat berat berdasarkan peraturan perundang-undangan yang berlaku. Ketiga, melaksanakan tugas sebagai guru di daerah khusus/terpencil sekurangkurangnya selama lima tahun secara terus menerus atau selama delapan tahun secara terputus-putus. Keempat, berusia minimal 40 tahun dan belum pernah menerima penghargaan yang sejenis di tingkat nasional. Kelima, responsif terhadap persoalanpersoalan yang aktual dalam masyarakat. Keenam, dengan keahlian yang dimilikinya membantu dalam memecahkan masalah pendapat, secara lisan atau tertulis; kesediaan untuk mendengar/menghargai pendapat orang lain; sopan santun dan susila; disiplin kerja; tanggung jawab dan komitmen terhadap tugas; kerjasama; dan stabilitas emosi.

Dimensi memiliki jiwa pendidik mencakup beberapa hal. Pertama, menyayangi dan mengayomi peserta didik berkebutuhan khusus. Kedua, memberikan bimbingan secara optimal kepada peserta didik berkebutuhan khusus. Ketiga, mampu mendeteksi kelemahan belajar peserta didik berkebutuhan khusus. Pemilihan guru berprestasi serta pemberian penghargaan kepada guru SD di Daerah Khusus dan guru PLB/PK berdedikasi seperti disebutkan di atas merupakan agenda tahunan. Namun demikian, meski sifatnya kegiatan tahunan, program ini bukanlah sebuah kegiatan yang bersifat seremonial belaka. Pelembagaan program ini merupakan salah satu bukti kuatnya perhatian pemerintah dan masyarakat terhadap profesi guru. Tentu saja, di masa datang, kualitas dan kuantitas pemberian penghargaan kepada guru berprestasi dan berdedikasi senantiasa perlu ditingkatkan.

\section{Penghargaan Tanda Kehormatan Satyalancana Pendidikan}

Sejalan dengan disahkannya Undang-Undang Nomor 14 Tahun 2005 tentang Guru dan Dosen, guru berprestasi dan berdedikasi memiliki hak atas penghargaan sesuai dengan prestasi dan dedikasinya. Penghargaan tersebut diberikan kepada guru pada satuan pendidikan atas dasar pengabdian, kesetiaan pada lembaga, berjasa pada negara, maupun menciptakan Karya yang luar biasa.Kebijakan Pengembangan Profesi Guru Badan PSDMPK-PMP 69 Kriteria guru yang berhak menerima penghargaan Satyalancana Pendidikan, meliputi persyaratan umum dan persyaratan khusus. Persyaratan umum antara lain warga negara Indonesia; berakhlak dan berbudi pekerti baik; serta mempunyai nilai dalam DP3 amat baik untuk unsur kesetiaan dan sekurangkurangnya bernilai baik untuk unsur lainnya. Persyaratan khusus meliputi, pertama, diutamakan yang bertugas/pernah bertugas di tempat terpencil atau tertinggal sekurang- 
kurangnya selama lima tahun terus menerus atau selama delapan tahun terputus-putus. Kedua, diutamakan yang bertugas/pernah bertugas di daerah perbatasan, konflik, dan bencana sekurang- kurangnya selama 3 tahun terus menerus atau selama 6 tahun terputusputus. Ketiga, diutamakan yang bertugasselain di daerah khusus sekurang-kurangnya selama 8 tahun terus menerus dan bagi kepala sekolah sekurangkurangnya bertugas 2 tahun. Keempat, berprestasi dan/atau berdedikasi luar biasa dalam melaksanakan tugas sekurang-kurangnya mendapat penghargaan tingkat nasional. Kelima, berperan aktif dalam kegiatan organisasi/asosiasi profesi guru, kegiatan kemasyarakatan dan pembangunan di berbagai sektor. Keenam, tidak pernah memiliki catatan pelanggaran atau menerima sanksi sedang dan berat menurut peraturan perundang-undangan. ${ }^{7}$

\section{Penghargaan bagi Guru yang Berhasil dalam Pembelajaran}

Tujuan lomba keberhasilan guru dalam pembelajaran atau lomba sejenis dapat memotivasi guru untuk lebih meningkatkan profesionalismenya, khususnya dalam kemampuan perancangan, penyajian, penilaian proses dan hasil pembelajaran atau proses bimbingan kepada siswa; dan meningkatkan kebiasaan guru dalam mendokumentasikan hasil kegiatan pengembangan profesinya secara baik dan benar. Lomba keberhasilan guru dalam pembelajaran atau sejenisnya dilaksanakan melalui beberapa tahapan.

a. Sosialisasi melalui berbagai media, antara lain penyusunan dan penyebaran poster dan leaflet.

b. Penerimaan naskah.

c. Melakukan seleksi, baik seleksi administrasi maupun seleksi terhadap materi yang ditulis. Para finalis melaksanakan presentasi dan wawancara di hadapan dewan juri yang memiliki keahlian di bidang masing-masing. Sejalan dengan itu, aktivitas yang dilakukan adalah sebagai berikut: penyusunan pedoman lomba keberhasilan guru dalam pembelajaran atau sejenisnya tingkat nasional; penilaian naskah lomba keberhasilan guru dalam pembelajaran ${ }^{8}$

\section{Penghargaan Guru Pemenang Olimpiade}

Era globalisasi menuntut SDM yang bermutu tinggi dan siap berkompetisi, baik pada tataran nasional, regional, maupun internasional. Sejalan dengan itu, guru-guru bidang studi yang termasuk dalam skema Olimpiade Sains Nasional (OSN) merupakan salah satu diterminan utama peningkatan mutu proses dan hasil pembelajaran. Kegiatan OSN untuk Guru (ONS Guru) Kebijakan Pengembangan Profesi Guru - Badan PSDMPK-PMP 70 merupakan salah satu wahana untuk meningkatkan mutu proses dan hasil pembelajaran mata pelajaran yang tercakup dalam kerangka OSN. Olimpiade Sains Nasional (OSN) untuk Guru merupakan wahana bagi guru menumbuhkembangkan semangat kompetisi dan meningkatkan kompetensi profesional atau akademik untuk

${ }^{7}$ Masnur Muslich, Sertifikasi Guru Menuju Profesionalisme Pendidik. (Cet. I; Jakarta; PT Bumi Aksara, 2020), h. 12.

${ }^{8}$ Sudarma Momon, Profesi Guru:Dipuji, Dikritisi, Dan Dicaci (Jakarta: PT Raja Grafindo Persada, 2013), h. 23. 
memotivasi peningkatan kompetensinya dalam rangka mendorong mutu proses dan luaran pendidikan. Tujuannya adalah (1) menumbuhkan budaya kompetitif yang sehat di kalangan guru; (2) meningkatkan wawasan pengetahuan, motivasi, kompetensi, profesionalisme, dan kerja keras untuk mengembangkan IPTEK; (3) membina dan mengembangkan kesadaran ilmiah untu mempersiapkan generasi muda dalam menghadapi pemberdayaannya agar pengetahuan dan wawasan mereka selalu berkembang. ${ }^{9}$

Dengan kemajuan ipteks. Program kerjasama peningkatan mutu pendidik antar negara Asia, dalam hal ini dengan The Japan Foundation, misalnya, merupakan kelanjutan program-program yang telah dilaksanakan sebelumnya. Program kerjasama ini dilaksanakan untuk memberikan penghargaan kepada guru berprestasi dengan memberikan pengalaman dan wawasan tentang penyelenggaraan pendidikan dan budaya di negara maju seperti Jepang untuk dijadikan bahan pembanding dan diimplementasikan di tempat tugas mereka.Kontinuitas pelaksanaan program kerjasama ini sangat penting, karena sangat bermanfaat bagi para guru untuk meningkatkan Kebijakan Pengembangan Profesi Guru - Badan PSDMPK-PMP 71 pengetahuannya dalam melaksanakan tugas profesionalnya.

\section{Pembinaan dan Pemberdayaan Guru Berprestasi dan Guru Berdedikasi}

Guru memiliki peran yang sangat penting dan strategis dalam membimbing peserta didik ke arah kedewasaan, kematangan dan kemandirian, sehingga guru sering dikatakan sebagai ujung tombak pendidikan. Untuk melaksanakan tugasnya, seorang guru tidak hanya memiliki kemampuan teknis edukatif, tetapi juga harus memiliki kepribadian yang dapat diandalkan sehingga menjadi sosok panutan bagi siswa, keluarga maupun masyarakat. Selaras dengan kebijaksanaan pembangunan yang meletakkan pengembangan sumber daya manusia sebagai prioritas pembangunan nasional, kedudukan dan peran guru semakin bermakna strategis dalam mempersiapkan sumber daya manusia yang berkualitas dalam menghadapi era global. ${ }^{10}$ Untuk itu, kemampuan profesional guru harus terus menerus ditingkatkan. Prestasi yang telah dicapai oleh para guru berprestasi perlu terus dijaga dan dikembangkan, serta diimbaskan kepada guru lainnya. Oleh karena itu, sebagai tindak lanjut dari pelaksanaan pemilihan guru berprestasi, perlu dilaksanakan pembinaan dan

\section{Penghargaan Lainnya}

Penghargaan lainnya untuk guru dilakukan melalui program kerjasama pendidikan antar negara, khususnya bagi mereka yang berprestasi. Kerjasama antar negara ini dilakukan, baik di kawasan Asia maupun di kawasan lainnya. Kerjasama antarnegara bertujuan untuk meningkatkan pemahaman dan saling pengertian antaranggotanya. 2013), h. 57.

${ }^{9}$ Abd.Rahman Getteng, Menuju Guru Profesional dan Ber-Etik (Yogyakarta:grha guru guru, 96.

${ }^{10}$ Ondi saondi dan Aris Suherman, etika profesi keguruan (Bandung: Refika Aditama : 2010 ), h. 
Melalui kerjasama ini, guru-guru berprestasi yang terpilih diberi kesempatan untuk mengikuti pelatihan singkat bidang keahlian atau teknologi pembelajaran, studi kebudayaan, studi banding, dan sejenisnya. Kerjasama ini antara lain telah dilakukan dengan negara- negara Asean, Jepang, Australia, dan lain-lain. Penghargaan lainnya yang diberikan kepada guru adalah Anugerah Konstitusi tingkat nasional bagi guru Pendidikan Kewarganegaraan (PKn) untuk semua jenis dan jenjang. Penerima penghargaan ini adalah guru-guru PKn terbaik yang diseleksi secara berjenjang mulai dari tingkat sekolah, kabupaten/kota, provinsi, sampai ke tingkat nasional. ${ }^{11}$

\section{SIMPULAN}

Penghargaan terhadap guru sangat tepat dan bermanfaat. Karena dengan adanya penghargaan guru dapat diapresiasi hasil kerjanya dan dapat meningkatkan fungsi guru tersebut. Juga dengan adanya penghargaan seseorang yang berprofesi guru dapat bekerja dan berkarya dengan rasa aman dan nyaman tanpa ada tekanan dari pihak lain. Dengan adanya perlindungan dan penghargaan terhadap guru yang bekerja dalam ruang lingkup pendidikan maka akan tercapainya tujuan, visi, dan misi dari pendidikan di Indonesia yang dirancangkan oleh Kementrian Pendidikan Republik Indonesia.

\section{DAFTAR PUSTAKA}

Endang Komara, "Perlindungan Profesi Guru di Indonesia". MIMBAR PENDIDIKAN:Jurnal Indonesia Untuk Kajian Pendidikan, Vol. 1(2) September, Bandung, Indonesia: UPI, h.155.

Getteng, Abd.Rahman. Menuju Guru Profesional dan Ber-Etik Yogyakarta: grha guru, 2013.

Imron, Ali. Kebijakan Pendidikan di Indonesia. Jakarta: Bumi Aksara, 2016.

Jakarta: Bumi Aksara

Momon Sudarma, Profesi Guru:Dipuji, Dikritisi, Dan Dicaci (Jakarta: PT Raja Grafindo Persada, 2013), h.272

Muslich, Masnur. 2009. Sertifikasi Guru Menuju Profesionalisme Pendidik.

Ridlo Muhammad, "Pengaruh Pemberian Penghargaan dan Kesejahteraan Terhadap Kinerja Guru MTsN SE-KABUPATEN NGAWI.” 2017, h.19

${ }^{11}$ https://pdfslide.net/documents/makalah-perlindungan-dan-penghargaan-gurudocx.html diakses pada tanggal 23 Oktober 2020 pada Jam 22:20 
Saondi, Ondi dan Aris Suherman. Etika Profesi Keguruan. Bandung: Refika Aditama, 2010.

Satori, Djaman, dkk. 2014. Profesi Keguruan. Tangerang Selatan: Universitas

Sudarma Momon, Profesi Guru:Dipuji, Dikritisi, Dan Dicaci Jakarta: PT Raja Grafindo Persada, 2013

Suryoubroo. Beberapa Aspek Dasar Kependidikan, Jakarta: Bina Aksara, 1983.

Terbuka

Undang-Undang Republik Indonesia Nomor 14 Tahun 2005 Tentang Guru dan Dosen

Undang-Undang Rrepublik Indonesia Nomor 20 Tahun 2003 tentang Sistem Pendidikan Nasional 